\title{
喉頭・気管狭窄症
}

\author{
多田靖宏・鈴木輝 久. 岡野渉 \\ 今泉光雅・谷覀希子.大森孝一
}

\section{Laryngo-tracheal Stenosis}

\section{Yasuhiro Tada, Teruhisa Suzuki, Okano Wataru Mitsuyoshi Imaizumi, Akiko Tani and Koichi Omori}

Key words : laryngeal stenosis, tracheal stenosis, artificial trachea, regeneration, tissue engeneering

\section{は じめに}

喉頭・気管狭窄は，気道閉塞症状を呈し嗄声のみならず 呼吸困難を呈するために慎重な対応が必要な疾患で難治性 であることが多い，狭窄の原因は感染症，外傷，腫瘍，長 期気管内挿管や気管切開術後の合併症などであり，狭窄の 程度も様々であるため治療は個々の病態によって適切な判 断が必要となる。本稿では, 喉頭・気管狭窄症の診断や治 療について述へ，良好な結果を得た例と，難渋した例を呈 示して報告する。

\section{原因}

狭窄の原因を表 1 に示す. 外傷, 熱傷, 気管切開術後, 気管挿管によるものなどは耳鼻咽喉科として経験する疾患 であるが，再発性多発軟骨炎や類天疮瘡などは比較的稀で あり，耳鼻咽喉科医単独での治療は難しく，他科との連携 が重要である，検査時に確定診断に至らない場合でも，後

表 1 喉頭・気管狭窄症の原因

\begin{tabular}{l}
\hline 外傷 \\
熱傷 \\
有機溶剤などの誤飲 \\
手術 (気管切開術、輪状甲状間膜穿刺術) \\
気管挿管 \\
腫瘍性疾患による進展・圧排 \\
気管軟化症 \\
骨・軟骨異常 \\
再発性多発軟骨炎 \\
結核 \\
類天疮瘡 \\
先天性 \\
特発性
\end{tabular}

日病状が進行して確実例に移行する場合もあるため治療の 開始時期は慎重に決める必要がある。

\section{診断}

狭窄の有無を判断するには喉頭内視鏡検査が最も簡便で 有用な方法である。声門上から声門, 声門下の観察は重要 で，可能であれば喉頭麻酔を行い，声門を越えて実際に声 門下まで直接内視鏡を挿入して観察すると良い。また，気 管切開孔があれば，そこから上方に声門下を観察するのも 有用である。声門上から声帯の可動性や声門閉鎖の有無な どが明確に判断できない場合も，声門下の観察では明らか になる場合がある，ただし，内視鏡のみでは狭窄が粘膜病 変であるのか軟骨病変であるかは判別が困難である.

画像検査としては，CT P MRIは，狭窄の程度や範囲を 詳細に把握することができる，狭窄部位が粘膜病変か軟骨 病変かの判断が可能であり, 治療を考える上で重要であ る、内腔を計測することで, 治療に用いる Tチューブやカ ニューレのサイズを事前に決定することも可能となる，水 平断・冠状断・矢状断の 3 面で評価すると状況を把握しゃ すくなり, 更に, 三次元再構築を行うことで病変を立体的 に捉えることができ有用である。

$$
\text { 治療 }
$$

狭窄の程度により治療方針は様々であるが，当教室での 一般的な方針を述べる。

まず，狭窄が軽度で呼吸苦を呈さない場合は保存的治療 を選択する，原因にもよるが，腫瘍性病変でなければ，ま ずはステロイドの吸入療法や内服から開始する。狭窄が中 等度以上で呼吸困難を来す場合は, 積極的に気管切開術を 施行している。狭窄の範囲が限局する場合は, 内腔からの アプローチとして直達喉頭鏡下レーザー切除術を選択する 場合もある。

\section{福島県立医科大学医学部耳鼻咽喉科学講座}

Department of Otolaryngology, School of Medicine, Fukushima Medical University 
狭窄が全周性，瘏痕が長軸方向に広範囲，支持軟骨が欠 損しているなどの症例に対しては，外切開を用いた手術が 良い適応となる。まずは㓔痕組織の切除と内腔の拡大を目 的に喉頭・気管溝を形成する。この際に, 㓔痕組織切除後 の創面が出来るだけ raw surfaceとならないように口唇粘 膜や頬粘膜を移植し，ステントを留置する，以前はステン トとして手術用手袋の拇指の中にシリコン製耳栓を詰めた ものを用いていたが，最近はTチューブを用いることが増 えている. 当院では約 6 カ月間ステントを留置した後で抜 去し, 約 2 週間は再狭窄が起きないことを確認してから喉 頭・気管溝を閉鎖している。悪性腫瘍の場合は，腫瘍と喉 頭気管を合併切除し，一期的に再建することもある．再建 (閉鎖)の一つの方法として, われわれは, 気道の臓器の 機能的再生をはかり, Quality of Lifeの向上を実現するこ とを目的に, 2002 年より生体内組織再生誘導の手法で, 人工材料を用いた気道の再生医療の臨床応用を行ってき た。用いている人工気管は，筒状のポリプロピレンメッ シュの内腔と外側にコラーゲンスポンジを付加した構造と なっている，再建術は，失損部位に対してやや大きめにト リミングした人工気管に自己の末梢血を浸して被覆しナイ ロン糸で縫合固定する。喉頭・気管溝と気管切開孔が別に 存在する場合は，同時に閉鎖するが，気管切開孔はhinge flapで閉鎖するようにしている.

\section{術 後 管 理}

術後は, 感染防止に第二世代セフェム系の静注を 5 日程
度行い，その後はマクロライド系の内服薬を投与してい る。 その他に, 去痰剂の蒸気吸入, 肉芽防止にトラニラス 卜，胃酸の逆流防止に消化管運動賦活剤などを投与してい る.

\section{気道再建術の適応}

基礎疾患として糖尿病を有する患者, 膠原病関連疾患で ステロイドや免疫抑制剂などを要する患者などで易感染性 が疑われる場合は手術を見合わせている，また，喀痰培養 検査でMRSAが検出されている場合は，術前に除菌する ようにしている。

人工気管を用いた再建術は頸部気管の部分欠損が最も良 い適応であり，輪状軟骨も弓部の再建は可能である。動物 実験では全周性欠損に対する環状移植は $5 \mathrm{~cm}$ 程度までは 成功しているが，現時点では臨床応用は行われていない。 胸部気管抒よび気管分岐部もヒトへの応用は行われていな い.

\section{症 例 呈 示}

1）良好な結果を得た例

特発性喉頭気管狭窄症の例を提示する。

29 歳，女性。平成 7 年 10 月頃，特に誘因無く呼吸苦が 出現し近医耳鼻咽喉科を受診した。CTにて全周性の声門 下狭窄と診断された。気管挿管の既往もなく，自己免疫疾 患も認めなかった。平成 8 年 3 月から平成 9 年 7 月までに 合計 4 回の狭窄症手術を受けたが，再狭窄を来し Tチュー

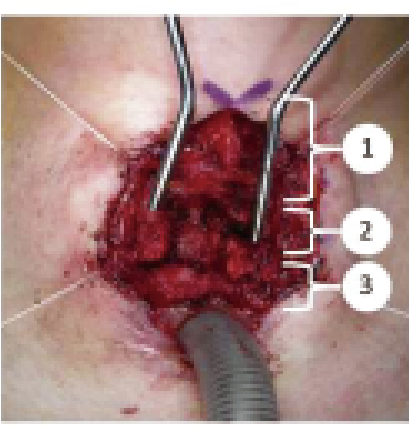

A

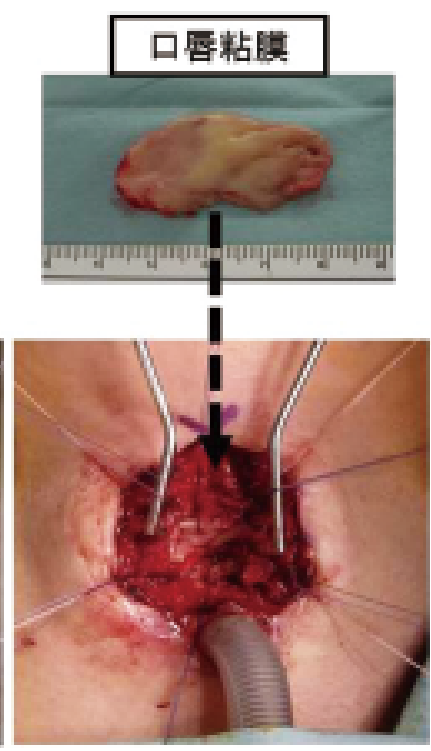

\section{B}

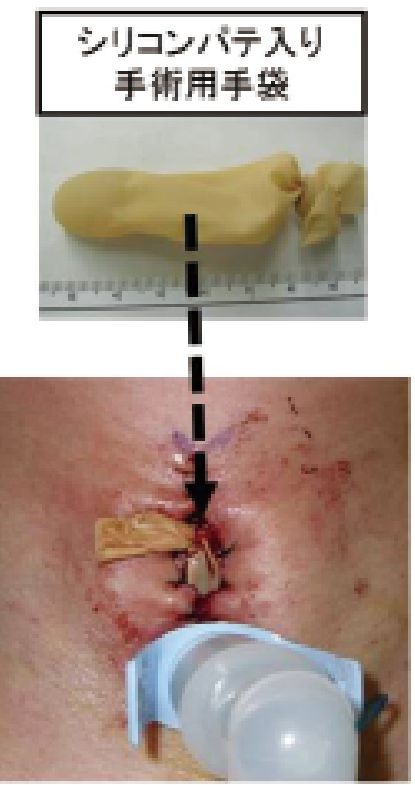

C

図 1 喉頭 ·気管溝形成術

A．狭窄部位の軟骨切除 (1)甲状軟骨(2)輪状軟骨(3)気管軟骨)

B. 内腔の㓔痕組織を除去し口唇粘膜を移植

C. 喉頭・気管溝にシリコン入り手術用手袋をステントとして挿入 


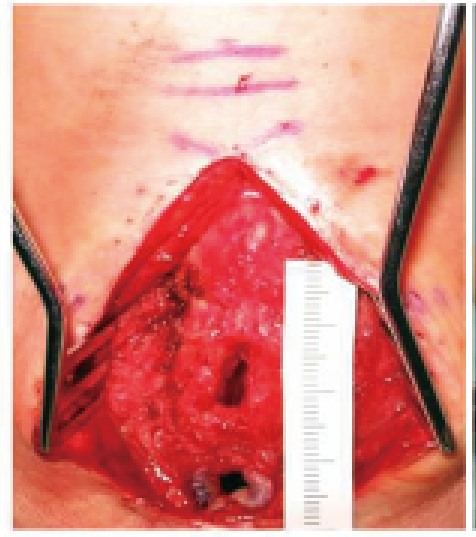

A

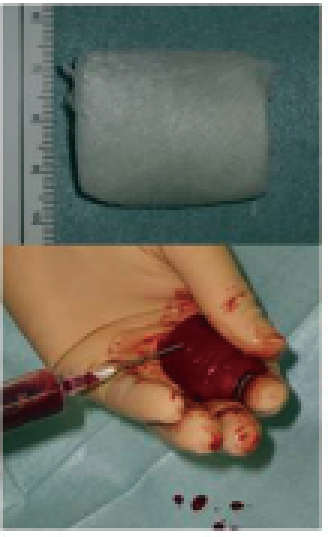

B

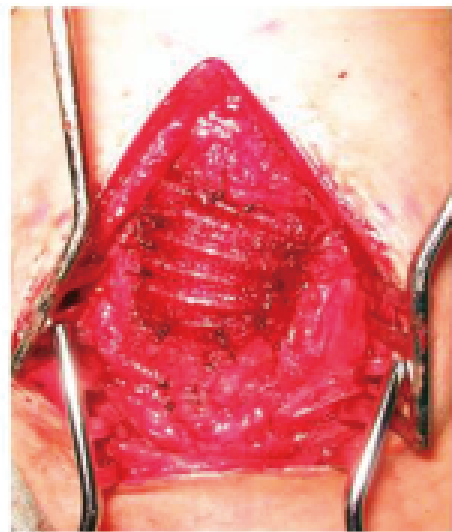

C

図 2 人工気管を用いた再建術
A. 喉頭・気管溝を確認 $(15 \times 5 \mathrm{~mm})$
B. 人工気管をトリミングして自己の血液で湿潤 $(25 \times 22 \mathrm{~mm})$
C. 喉頭・気管溝に人工気管を被覆し縫合固定

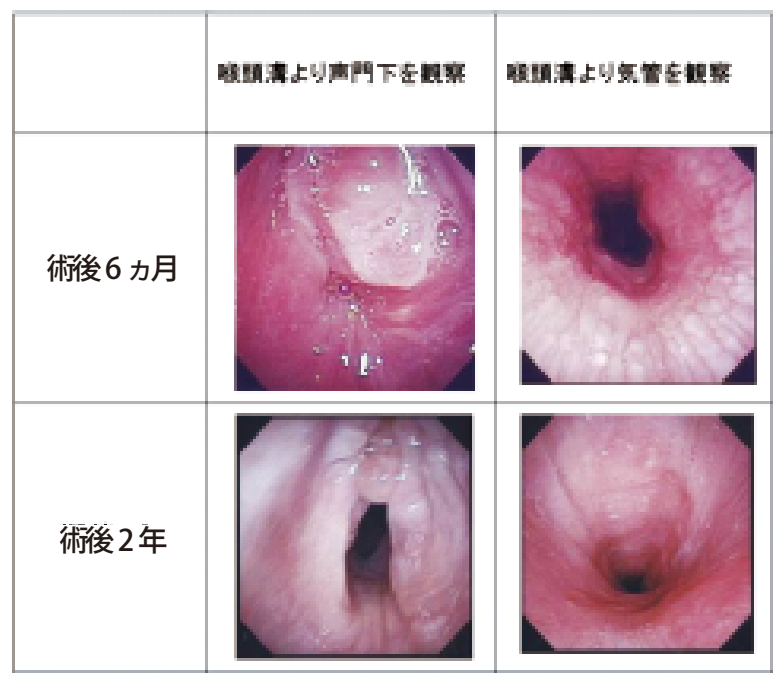

図 3 再発性多発軟骨炎例

術後 6 力月時には声門下肉芽が存在し, 気管粘膜には 発赤と浮腫がみられた. ステロイド内服を開始して 術後 2 年が経過した時点では声門下の肉芽は縮小し, 気管粘膜の炎症も軽減している.

ブ管理となり, 平成 17 年 7 月当科紹介となった.

喉頭・気管溝形成術を施行した（図 1)。輪状軟骨から 第 2 気管輪の範囲に㓔痕組織を認め切除し (図 1A), raw surface となった部分に口唇粘膜を移植し（図1B), 作成 した喉頭・気管溝にはステントとしてシリコンパテ入り の手術用手袋を挿入した（図 1C)，2 週間程度でTチュー ブに交換した。喉頭・気管溝形成より約 6 カ月後に $\mathrm{T}$ チューブを抜去し再狭窄が無いことを確認した。

気道再建手術を施行した（図2)。喉頭・気管溝（図
2A）よりも大きめにトリミングした人工気管（図 2B）を 被覆し, 縫合固定した (図 2C). 気管孔は別に hinge flap で閉鎖したうえで一期的に創部を閉鎖した。その後，再 狭窄は認めていない.

2) 再建まで至らなかった例

再発性多発軟骨炎の例を提示する (図 3).

17 歳, 男性. 他院にて平成 18 年 3 月に声門下狭窄の 診断にて気管切開術をうけカニューレ管理となり, 平成 19 年 6 月に当科紹介となった。まず㑨頭・気管溝形成術 を行った。しかし, 術後に声門下に肉芽様組織が増生し, 6 力月後より気管軟骨炎と耳介軟骨炎が出現した。再発性 多発軟骨炎の診断にてステロイド内服開始となった，現 在, 肉芽は縮小し気管の炎症も軽快しているが, ステロ イド内服継続中のため再建術には至っていない.

$$
\text { ま と め }
$$

喉頭・気管狭窄症について, 当科での診断から治療ま での展開について述べた。治療の際には，原因と原疾患 を見極め, 病状を正確に把握し1つ1つの行程を急がず に充分な観察期間を設定することが大切と考える.

\section{参 考 文 献}

1) Langer R, Vacanti JP : Tissue engineering. Science $260: 920-92,1993$.

2）大森孝一, 中村達雄, 金丸眞一ほか：組織工学から見 た臟器再生一気管・気管支の再生治療一。日臨麻会 誌 $25(3): 310-315,2005$.

3) Nakamura T, Teramachi M, Sekine $\mathrm{T}$ et al : Artifical trachea and long term follow-up in carinal reconstruction in dogs.Int J Artif Organs 23:718-724, 
2000.

4) Omori K, Nakamura $T$, Kanemaru $S$ et al : Regeneratuve medicine of the trachea: The first human case. Ann Otol Rhinol Laryngol 114 (6) : 429 433, 2005.

5) Tada Y, Suzuki T, Takezawa $T$ et al : Regeneration of tracheal epithelium utilizing a novel bipotential collagen scaffold. Ann Otol Rhinol Laryngol, 117 (5) : 359-365, 2008.

6) Tada Y, Takezawa T, Tani A et al : Collagen vitrigel scaffold for regenerative medicine of the trachea: Experimental study and quantitative evaluation. Acta Oto-Laryngologica, 132: 447-452, 2012.
7）大森孝一, 中村達雄, 多田靖宏ほか：「第109回日本 耳鼻咽喉科学会シンポジウム」耳鼻咽喉科臨床の進 歩 一喉頭・気管の再生医療 - . 日耳鼻 $112: 104$ $109,2009$.

8）大森孝一, 中村達雄, 多田靖宏ほ力：「第109回日本 気管食道科学会シンポジウム」頭頸部・気管食道科領 域の再生医療一気管の再生医療一。日気食会報 $62: 84-85,2011$.

別刷請求先 テ 960-1295 福島県福島市光が丘 1 番地 福島県立医科大学医学部耳鼻咽喉科学講座

多田靖宏 